\title{
NAME OF THE NEWSPAPER: COMMUNICATIVE-FUNCTIONAL APPROACH
}

\author{
Liliya R. Muhametzyanova ${ }^{1}$ \\ Leyla A. Mardieva² \\ Elena S. Kara-Murza ${ }^{3}$
}

\begin{abstract}
The article is devoted to the linguistic status of hemeronyms - the names of media publications - on the material of newspaper titles. They represent a variety of proper names and are qualified as a word / wordform, sentence or primitive text, being the subject of research of various disciplines - onomastics, syntax and text linguistics.
\end{abstract} In addition, the names of publications are in the focus of attention of specialists in the field of media design and marketing communication (more specifically naming). The functional approach to the object under study allows us to emphasize a specific goal setting of the identification / individualization of the media market object and to focus on three variants of the indicated names: a) as a structural element (subtext) of the integral complex sign, which is the aggregate text of the publication - the collective and periodic intellectual product functioning in a market economy; the name represents the core element of the header / title complex - as a rule, it has a polycode character, which is manifested also metagraphemically (through the headset, font size, font color), and illustratively (with the help of drawings, emblems, awards); b) as an independent element (primitive text) of marketing discourse (on city and office signboards and indexes) and c) as a nominative unit in works of various styles and genres on the functioning of print media (in subscription catalogs, in consumer dialogues at newspaper kiosks, in the news, analytics, etc.). The proposed communicative-functional approach to the study of the names of periodicals helps to apply the integrative models to its description, which in turn makes possible the most complete

\footnotetext{
${ }^{1}$ Kazan Federal University.

${ }^{2}$ Kazan Federal University.

${ }^{3}$ Moscow State University. aklilya@bk.ru.
} 


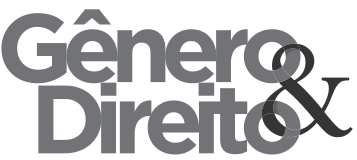

representation of the various semiotic methods of reflecting the pragmatic attitudes of publishers in it.

Keywords: newspaper, title, hemeronym, title / headline text, market model of mass communication

\section{Introduction}

The problem of language nomination is central to linguistics. Studies in this area are inherently inexhaustible, because they reflect the evolution of the world and man in this world, the constant development of cognitive and creative abilities of the human consciousness and the activity of dynamic processes in language [1]. A particular turning point in the sphere of nomination is the problem of the object; in this connection, the common names and proper names are contrasted.

Naturally, along with the dynamics of the language, the dynamics of scientific research in the field of "linguistic documentation" [2] of reality - onomastics - is also observed. Within this field, ergonomics, a direction studying an artificial nomination in the field of the names of the most diverse products of industry and intellectual
Periódico do Núcleo de Estudos e Pesquisas sobre Gênero e Direito Centro de Ciências Jurídicas - Universidade Federal da Paraíba V. 8 - No 05 - Ano 2019

ISSN | 2179-7137 | http://periodicos.ufpb.br/ojs2/index.php/ged/index

creativity functioning in market economy, becomes really actual.

The object of our scientific interest is the names of periodicals. Any study begins with the problem of terminology and the establishment of the scientific status of the object under study, the theoretical and methodological grounds for its description.

\section{Materials and Methods}

To denote periodicals, many terms correlated with different scientific directions are used. The lack of unity in the designation of this group of names indicates the complex and multifaceted nature of the research facility and the need to study it using various methods.

In the media industry the most common is the term "title" (which means "names of periodicals", "names of newspaper publication / newspaper", etc.) along with the terms "title" / "headline", "header / heading".

The term "heading" reflects the generality of the basic functional and communicative properties of the newspaper title with the names of works of any styles and genres. However, with regard to the designation of the name of the newspaper, it does not seem suitable 


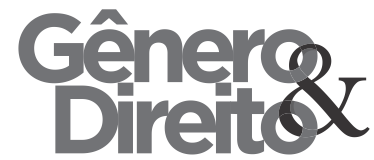

due to the connection of this term with the name of a separate newspaper/magazine publication and the uncertainty of the semantics of this word in the Russian language.

The terms "title", "title complex" emphasize that the title of the periodicals is a part of the headline complex of the newspaper and is designed in accordance with the genre and thematic specifics of the publication, the target audience, etc.

The term "newspaper logo" actualizes the fact that the name of the media edition is a special product of advertising creativity, a special component of marketing communication is the most important means of individualizing the publication on the media market. The complex of information of an identifiable and identifying character is indicated by the terms "title section", "title complex".

Linguistically, the designation of periodicals of any type (including newspapers) is conducted by means of proper names. The homonymical status of the names of this group is approved by A.V.Superanskaya [3] and is reinforced by the fact that the term "hemeronym" appears in linguistics [4].
Periódico do Núcleo de Estudos e Pesquisas sobre Gênero e Direito Centro de Ciências Jurídicas - Universidade Federal da Paraíba V. 8 - No 05 - Ano 2019 ISSN | 2179-7137 | http://periodicos.ufpb.br/ojs2/index.php/ged/index

Even a cursory glance at the library catalog of periodicals shows the diversity of the linguistic nature of these denominations. They are not only a) prepositional-case forms of nouns as incomplete implementations of proposals ("On the raid", "For the Motherland") and b) other lexicalgrammatical classes of words ("Tomorrow"), wider than nouns; but also c) key word combinations ("The New Kazan word", "My newspaper"); d) series of word forms related to the construction without conjunctions ("Business, banks, stock exchange") and cohesive links ("Time and money"); d) the subordinate parts of compound sentences ("Where is the money?") and д) самостоятельные предложения «Доживем до понедельника», «Я молодой»); e) independent proposals "We will live till Monday", "I am young"); e) complex names with an explanatory part ("The New Kazan Vecherka: Nezavisimaya Gazeta"). The functional approach allows us to agree with the position of A.K.Matveev: "... If necessary, you can "create" your own names from any language material. Names, being a sign of singling out a subject from a number of similar ones, can be a word, a word combination, and 


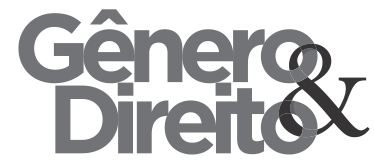

a sentence, because they go beyond the scope of vocabulary. ... A word is only one hypostasis of a name" [5].

Any onym is an "identifying sign": it serves as a means of identifying and individualizing of an object. The degree of individualization of the proper name is different, along with the names denoting one unique object, there are names that serve as the designation of a group of objects - "group proper names" [3]. As for the hemeronyms, this class of names has its own special type of individualization - the right to "mark the whole set of regularly published texts, united by the information concept and the policy of the relevant media" [6].

The question of the relevance of the hemeronyms as a variety of onyms to the category of utterances / texts remains controversial.

The main functions of nominal names are nominative and significative, whereas communicative and pragmatic are secondary and optional. A characteristic feature of proper names is their pronounced communicative character: "they acquire communicative significance in the process of interaction and are characterized by the ascertaining intonation inherent in nominative sentences" [7]. In speech, proper names
Periódico do Núcleo de Estudos e Pesquisas sobre Gênero e Direito Centro de Ciências Jurídicas - Universidade Federal da Paraíba V. 8 - No 05 - Ano 2019

ISSN | 2179-7137 | http://periodicos.ufpb.br/ojs2/index.php/ged/index can function in the nominative function of parts of sentences, and in the communicative aspect - in a calling or index function. In the latter case, structurally, this is a special type of single-component nominative sentences.

Modern science works out the concept of primitive text - "unusual from the point of view of classical linguistics, small text structures with a complete lack of special means of connectivity", whereas "the orientation of traditional linguistics primarily to the standardized coherent text as a source material of linguistic research gave the concept of words as "bricks" from which the sentences are composed [8]. The primitive texts "are oriented first of all at transferring the quintessence of the structure of wholeness in its purest form and therefore are quite sufficient for the solution of relatively simple communicative tasks", respectively, from the standpoint of "communicative reality" they are self-sufficient [8]. Among them, L.V.Sakharny mentions the titles of books, plays, movies, etc.

A study of hemeronyms in the concept proposed by L.V.Sakharny allows us to present the names of periodicals in all their linguistic 


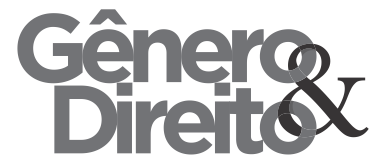

Periódico do Núcleo de Estudos e Pesquisas sobre Gênero e Direito Centro de Ciências Jurídicas - Universidade Federal da Paraíba V. 8 - $\mathrm{N}^{\circ} 05$ - Ano 2019

ISSN | 2179-7137 | http://periodicos.ufpb.br/ojs2/index.php/ged/index manifestations, and, most importantly, in the dynamics of communication.

Functional approach to the research object implies differentiation of medianames as primitive texts in the communicative space: 1) in the "Rospechat" catalogs "Newspapers and magazines" or library catalogs; 2) directly in the process of textual interaction, when in the field of view of the reader is not the deputy of this newspaper with its name, but the periodical itself as a collection of journalistic texts; 3 ) in texts of different styles and genres in cases where it is necessary to indicate a particular periodical. In the first case, the name of the publication from a linguistic point of view can be treated as a word = sentence, as a primitive text, as an independent speech communicative unit. In the second and third cases, the name of a periodical is usually considered as a nonindependent unit, as a structural element of the whole text (newspaper text or the reader's dialogue as a buyer with the seller of a newsstand).

The newspaper text in this case is legitimately understood as a complex intellectual and communicative product - a set of texts intended "for a particular publication, for publication in a certain place at a certain time" connected with a "concrete practical life situation", oriented to its type of audience [9]. The intent of publishers and owners embodied in the title of the publication unites a lot of texts into a single unit. This large-scale product can be characterized using terms such as "compound text" [10], a complex aggregate text [6].

\section{Discussion}

Among different news, journalistic and entertaining works that form a coherent text of the newspaper, the title of the publication, together with the elements adjoining it and cooperating with it, forms a special kind of identifying text - the title header text. This statement is proved by the following psychological, structural, compositional and semiotic facts:

1. With respect to the totality of the texts that make up the newspaper's number, the title occupies a separate and supra-textual position and is visually highlighted due to its location in the upper part of the first page of the newspaper and special graphic means.

2. The name of the newspaper can not be perceived and accordingly interpreted in isolation from its closest 
textual environment, since the name of the newspaper does not function in isolation, it is the core component of a set of interrelated elements that together with the proper name form a special semiotically complicated text of the identifying property, which is called "logotype", "title / title part", "title complex" of the publication in journalism and media design works. The verbal components of such a text in a newspaper are usually: the title of the publication, the "supra-headline" and / or "subtitle", the slogan, the shortened version of the newspaper's name, usually in the form of abbreviation (the last three elements are optional); type of publication and information about the founder; date, month and year of publication of the newspaper; the serial number of the newspaper, the frequency of publication; in some publications information about the price and circulation. Non-verbal figurative components of the text-title are: drawing and / or photograph, images of government awards, if any. Nonverbal graphic elements (rulers, frames, substrates) allow you to combine all the above components into a single textual whole.
The study of the media text is unlikely to be productive without taking into account its communicative status, which is understood as "a general functional purpose, meaningful either in terms of its finding in the field of knowledge (as a source of information, an artifact of the era) or with regard to its inclusion in general practical activity" [9]. Behind each name there is a name of the newspaper - "there is a group of people united by a commonness of ideas and views" [3] and it is the name together with other constituent parts of the given visual field that can express in extremely condensed form the publisher's leading intent of the publication, its purpose, the readership for which it is intended. Thus, it allows the target audience to identify the periodical, acting as a kind of regulator of relations between the publisher and potential readers. The title of the publication, together with the other components of the title header text, is thus a self-contained speech message.

\section{Results}

From the indicated positions we regarded the title headline of the newspaper published in the Republic of Tatarstan. The verbal components of this text: the actual name of the newspaper is 


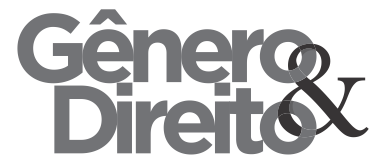

"The Star of the Volga Region" and its English version, the overhead titledefinition is Nezavisimaya Gazeta, the slogan "For Truth and Homeland!", the serial number, number and date of publication of the newspaper. Due to the actual graphic (use of capital letters) and meta-graphic (bold font, and its size), the key word of "hemeronym" "star" is updated.

The key words of the slogan and the headline of the homeland, truth, independence specify the intentional direction of the publication and are supported by the non-verbal component of the text - the representation of the precedent for Tatarstan image of the Tatar poet, Hero of the Soviet Union M. Jalil, leader of the underground antifascist Muslim organization sentenced to death by the fascist court. The precedent visual image [11] repeats the verbal message, emphasizes the nature of the printed publication - the opposition one, the purpose - serving the people. Thus, with the help of verbal and non-verbal components of the title heading (multimodal [12], [13], [14]), the publisher positions its newspaper, attracts its target audience and briefly reports on the content of the materials published in it [15].
Periódico do Núcleo de Estudos e Pesquisas sobre Gênero e Direito Centro de Ciências Jurídicas - Universidade Federal da Paraíba V. 8 - No 05 - Ano 2019

ISSN | 2179-7137 | http://periodicos.ufpb.br/ojs2/index.php/ged/index

In the conditions of commercialization of almost all spheres of life of Russian society, it is impossible not to take into account the commercial purpose of the object we are researching, its focus on promoting the newspaper as a media product in the market and receiving profit from publication. This is due to the fact that the name of the media along with other elements of the title header text forms a brand name and a trade mark of the publication, its logo, performing an advertising function. This function of the hemeronym makes it an object of study in advertising / advertology and the object of creativity in a special direction of creativity naming [16], [17].

\section{Conclusions}

Thus, the title of a periodical is one of ambiguous linguistic phenomena: it has the form of a word, phrases or sentences and the status of a text. The most productive for its study is the integrative approach, demanded by modern science, to the object under study, combining the achievements of linguistics, including onomastics, semiotics, marketing, including naming, and media design. In this case, the hemeronym appears in the process of 
communication in various manifestations, being considered both as a component of the whole text of the newspaper, and as a sign of company identification.

The hemeronym deserves further research. In advance, it can be assumed that the synthesis of the achievements of different scientific disciplines will allow: 1) to establish the patterns of the names of periodicals and their functioning in certain communicative situations and given space-time coordinates; 2) according to the constructive principle of the language of the newspaper, according to V.G.Kostomarov, to define a set of expressive and standard components of the title header complex, forms and methods of transferring explicit and implicit information; 3) to conduct a comprehensive analysis of the ways to create a competitive image of the periodical and mechanisms for forming a stable attachment to this media audience.

\section{Acknowledgements}

The work is performed according to the Russian Government Program of Competitive Growth of Kazan Federal University.

\section{References}

Guzel A. Golikova, Radif R.Zamaletdinov, Alsu H. Vafina \& Rezeda F. Mukhametshina The "New" Strategy in Teaching Literature in a Multiethnic Environment (as exemplified by the Republic of Tatarstan). International Journal of Environmental and Science Education. April 2016 Special Issue. pp. 1237-1246

Hintikka Y. Logic, language-games and information. Kantian thems in the philosophy oflogic. Oxford, 1973, X, $291 \mathrm{p}$.

Supernanskaya A.V. The general theory of the proper name. Moscow: Nauka, $1973.368 \mathrm{c}$.

Podolskaya N.V. Dictionary of Russian onomastic terminology / otv. ed. A.V.Supernanskaya. Ed. 2 nd, revised. and additional. Moscow: Nauka, 1988. $192 \mathrm{pp}$.

Matveev, A.K. The Apology of the Name / Questions of Onomastics. 2004. № 1. P. 7-13.

Golomidova M.V., Myasnikova V.A. The image of the addressee in the titles 


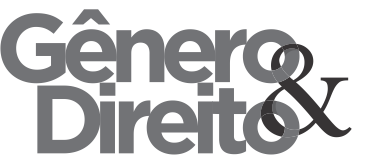

Periódico do Núcleo de Estudos e Pesquisas sobre Gênero e Direito Centro de Ciências Jurídicas - Universidade Federal da Paraíba V. 8 - $\mathrm{N}^{\circ} 05$ - Ano 2019 ISSN | 2179-7137 | http://periodicos.ufpb.br/ojs2/index.php/ged/index

of periodicals // Onomastics. 2014. No. 2

(17). Pp. 112-119.

Berger, A.A. (2015). Ads, Fads \&

Consumeer Culture. New-York.

Ufimtseva A.A. Lexical nomination (primary neutral) // Language nomination (types of titles) / Otv. Ed. B. A. Serebrennikov, A. A. Ufimtseva. M .: Nauka, 1977. Pp. 5-85.

Sakharny L.V. Texts-primitives and patterns of their generation // Human factor in language: language and the generation of speech. Moscow: Nauka, 1991. P. 221-237.

9. Konkov V.I. Actual media: the principles of study // Uchenye zapiski Novgorodskogo gosudarstvennogo universiteta im. Yaroslava Mudrogo. 2015. №2. S.1-5.

Lazareva, E. Headline Text Complex - A Means of Organizing and Optimizing Perception, Izvestiya Ural State University. 2006. № 40. P. 158-166.

Mardieva L. Pre-existing visual images and phenomena: a linguistic approach //3rd International Multidisciplinary Scientific Conference on Social Sciences and Arts SGEM 2016, 24-31 August, 2016, Book 1 Vol. 3, 765-772 pp.

Rowman \& Littlefield, Lanham. 31 p.

Multimodal analysis (2009). The Handbook of Business Discourse, pp. 155-165.

Noah A. Smith and Jason Eisner. 2005. Guiding unsupervised grammar induction using contrastive estimation. In International Joint Conference on Artificial Intelligence (IJCAI) Workshop on Grammatical Inference Applications, Edinburgh, July.

D.Elliott and F.Keller. Image description using visual dependency representations. In Proceedings of the Conference on Empirical Methods in Natural Language Processing, pages 1292--1302, Seattle, WA, 2013.

Merriam's guide to naming. A practical guide to business naming. ByLisaDowneyMerriam. - 2-ndedition. - Red Toad Press, 2013. 35 p.

David A. Smith, Jason Eisner, Parser adaptation and projection with quasisynchronous grammar features, Proceedings of the 2009 Conference on 
Periódico do Núcleo de Estudos e Pesquisas sobre Gênero e Direito Centro de Ciências Jurídicas - Universidade Federal da Paraíba

V. 8 - $\mathrm{N}^{\circ} 05$ - Ano 2019

ISSN | 2179-7137 | http://periodicos.ufpb.br/ojs2/index.php/ged/index

Empirical Methods in Natural Language

Processing: Volume 2, August 06-07,

2009, Singapore 